\title{
Penilaian Persepsi Masyarakat Terhadap Bangunan Besejarah di Koridor Kayutangan, Malang, Indonesia
}

\author{
Baskoro Azis ${ }^{1 *}$, Herry Santosa ${ }^{2}$, Jenny Ernawati ${ }^{2}$ \\ ${ }^{1}$ Magister of Architecture, University of Brawijaya, Malang, Indonesia \\ ${ }^{2}$ Department of Architecture, University of Brawijaya, Malang, Indonesia \\ * Corresponding Author: baskoro.azis@gmail.com
}

\begin{abstract}
Keywords:

Visual quality,

Historical building,

Lighting, SD,

Perception

Malang is well-known for colonial buildings. Visual quality of historic buildings in the Kayutangan corridor makes it an icon of Malang City. Assessment of visual quality is affected by daytime conditions. Day lighting are factors that influenced the visual quality assessment of historic buildings. This study meant to assess the visual quality of historic buildings and aspects that influence by society during the day. This study used mix method descriptive quantitative and qualitative method explaining public perception about the visual quality of historical buildings in Kayutangan street corridors during the day. Semantic Differential Scale (SD) was the instrument to describe the respondents' perceptions (positive and negative ones). From the result showed that visual quality of 1 of 10 historic buildings in Kayutangan was below the average scores and the most influential variables by society with day lighting in the historic building.
\end{abstract}

\begin{abstract}
Abstrak:
Malang merupakan kota yang memiliki bangunan bersejarah cukup banyak. Kualitas visual dari bangunan bersejarah tersebut menjadikan salah satu karakter visual yang menonjol di kota Malang. Penilaian kualitas visual terpengaruh oleh pencahayaan di siang hari. Pencahayaan di siang hari membuat bangunan terlihat secara keseluruhan agar mempermudah penilaian terhadap kualitas visual bangunan bersejarah. Studi ini bertujuan untuk membahas penilaian kualitas visual terhadap bangunan bersejarah dan aspek yang mempengaruhi di siang hari. Studi ini menggunakan metode penelitian kuantitatif dengan persepsi masyarakat tentang kualitas visual bangunan bersejarah di koridor Kayutangan Kota Malang pada siang hari. Penelitina ini menggunakan Skala Semantik Diferensial untuk medeksripsikan persepsi responden. Hasil penelitian menunjukan bahwa kualitas visual dari sepuluh bangunan terdapat satu bangunan bersejarah di Kayutangan Malang memiliki penilaian dengan dibawah rata-rata dan terdapat 6 aspek yang paling berpengaruh terhadap bangunan bersejarah di siang hari.
\end{abstract}

Kata Kunci: Kualitas visual, Bangunan bersejarah, Pencahayaan, SD, Persepsi

@ 2017 The Authors. Published by GKAK UNMER Malang

*Corresponding Author: baskoro.azis@gmail.com 


\section{Pendahuluan}

Malang adalah kota yang memiliki banyak sejarah dalam bentuk bangunan kolonial. Keberadaan bangunan bersejarah di Indonesia sering kali tidak mendapat perhatian khusus. Kondisi bangunan bersejarah cenderung sangat memprihatinkan, baik secara fisik maupun fungsional. Daerah Kayutangan dulunya merupakan pusat perdagangan dan jalan utama di masa lalu. Namun, sekarang, kejayaan dan sejarahnya secara bertahap mulai memudar. Kondisi bangunan dialihkan secara visual oleh pembangunan perkotaan untuk dapat bersaing dengan daerah lain. Ini termasuk pengalihan gaya arsitektur tanpa memperhatikan konteks, membuat unsur-unsur bersejarah dari bangunan tidak terlihat. Keberadaan bangunan bersejarah dengan arsitektur kolonial yang khas menyediakan fitur yang dapat menarik perhatian publik di daerah tersebut.

Sementara itu, Sachari (2007) menyatakan bahwa arsitektur adalah elemen visual utama yang berfungsi sebagai dasar dari citra perkotaan melalui kegiatan desain kota sebagai aktualisasi nyata yang paling mudah dilihat secara visual dan dapat mewakili zamannya. Artinya, keberadaan kota tidak dapat dipisahkan dari sejarah dan bangunan sekitarnya. Karena itu, bangunan kolonial masih dipertahankan dan digunakan sebagai Heritage Track oleh pemerintah dan akademisi.

Koridor jalan Kayutangan, termasuk bentuk dan deretan bangunannya merupakan bangunan yang dipengaruhi oleh sejarah, fungsi, dan arsitektur bangunan, mudah diingat oleh masyarakat. Selain itu, salah satu faktor yang mempengaruhi penilaian masyarakat adalah faktor pencahayaan. Penglihatan manusia digunakan untuk menangkap keindahan visual mengarah persepsi dan informasi dari suatu objek melalui cahaya yang dipantulkan untuk menilai kualitas visual, terutama di gedung-gedung bersejarah. Pengabaian dan perubahan dalam bangunan dapat mempengaruhi fasad bangunan, secara otomatis menghasilkan kesan negatif atau hanya menguntungkan beberapa organisasi tertentu yang melihatnya. Kesan yang timbul sangat tergantung pada bagaimana individu menanggapi objek-objek ini dengan persepsi visual mereka. Kenyataannya, sebagian besar kesan yang dihasilkan pada objek bangunan ditentukan oleh persepsi visualnya. Salah satu alasan mengapa persepsi visual begitu penting dalam menafsirkan lingkungan kita adalah bahwa masing-masing kita merasakan objek, tetapi persepsi kita tentang apa yang dimaksud dengan situasi ideal sangat berbeda. Dengan demikian, persepsi visual sangat penting untuk dibahas untuk penilaian kualitas visual.

Kualitas visual adalah penilaian yang muncul dari persepsi, dan perasaan manusia ketika mereka melihat sesuatu atau terkait dengan indra visual. Visualisasi objek yang terlihat adalah kualitas visual yang dimiliki oleh objek yang terhubung dengan penilaian persepsi yang muncul ketika ditafsirkan. Imajinasi visual suatu daerah di suatu kota dapat memberikan kesan atau persepsi kepada pengamat. Kesan sebuah kawasan dipengaruhi oleh tiga aspek, yaitu identitas, Bentuk Dasar, dan makna (Lynch 1969). Nilai-nilai estetika visual dan bentuk-bentuk lingkungan akan memandu pengamat untuk memberi kesan atau persepsi atau merasa dengan indra visual mereka dari daerah tersebut Lynch (1969). Banyak penelitian telah membahas kualitas visual Kota Malang, khususnya di koridor jalan Kayutangan yang memiliki banyak sejarah yang tangible dan intangible. Lokasi ini sedang diperdebatkan dan dipelajari oleh banyak pihak. Namun, tidak ada peneliti yang melakukan penelitian aspek yang berpengaruh pada kualitas visual dengan cahaya pada siang di koridor jalan Kayutangan. Persepsi visual pengamat terhadap area jalan atau koridor juga dipengaruhi oleh elemen pendukungnya, yaitu pencahayaan. Reaksi pengguna terhadap bangunan di lingkungan dinyatakan oleh Boyce (1998) di IEA, bahwa pencahayaan alami maksimum sangat diperlukan untuk memenuhi kebutuhan dasar manusia, yaitu 
kebutuhan yang jelas untuk melihat dengan jelas di dalam ruangan dan mengalami stimulasi lingkungan dari efek pencahayaan.

Kualitas visual yang timbul karena efek pencahayaan dapat memicu seseorang untuk menjelajahi ingatan masa lalu untuk memberikan pendapat melalui pengalaman masing-masing. Berbeda dengan Manurung (2008) menjelaskan bahwa faktor pencahayaan pada siang hari dapat menghasilkan kesan yang aman dan menarik untuk bangunan. Pada efek lainnya, faktor pencahayaan pada malam hari memberikan kesan negatif yang didominasi oleh persepsi visual bahwa bangunan terlihat gelap, fuzzy, suram, dan membosankan. Kualitas visual dapat menarik untuk dikaji lebih dalam dengan membandingkan persepsi masyarakat melalui faktor pencahayaan. Hal ini karena faktor pencahayaan bangunan bersejarah pada siang hari mendapat respon yang kualitas visual dan persepsi yang baik oleh masyarakat.

Beberapa peneliti berfokus pada kualitas visual di gedung-gedung bersejarah pada siang hari (Askari and Dola, 2009; Perovic and Folic, 2012; Liu, Kang et al. 2015; Mahmoudi and Ahmad, 2015; Jennath and Nidhish, 2016). Di sisi lain, Kayutangan telah menjadi sebuah penelitian penting dari beberapa penelitian sebelumnya yang membahas kualitas visual (Karisztia, Pangarsa, dan Antariksa, 2008; Santosa et al., 2013, 2014; Fauziah, et al., 2012) Namun, mereka belum membahas aspek yang paling berpengaruh pada bangunan bersejarah yang terletak di Kayutangan dan kualtias visual bangunan bersejarah yang memiliki penilaian dibawah rata-rata.

Tujuan penelitian ini adalah untuk mengetahui variabel kualitas visual yang paling berpengaruh pada fasad bangunan bersejarah dengan pencahayaan siang hari. Masih belum ada yang penelitian lanjutan tentang variabel yang paling berpengaruh di lokasi kawasan Kayutangan. Sehingga pada kawasan ini, penelitian kualitas visual untuk mencari variabel yang berpengaruh menarik untuk diteliti.

Menganalisis kualitas visual dengan pengaruh pencahayaan terhadap kualitas visual akan memberikan informasi tentang seberapa besar dampak pencahayaan alami terhadap ruang publik atau bangunan. Pencahayaan yang sesuai dari sumber alami memungkinkan pengunjung untuk menikmati ruang publik atau arsitektur bangunan secara optimal, dan menciptakan kesan positif.

\section{Metode penelitian}

Penelitian ini merupakan penelitian dengan menggunakan metode campuran deskriptif kuantitatif dan kualitatif yang menggambarkan hasil data kuesioner responden di lapangan dengan merepresentasikan dalam bentuk persepsi masyarakat tentang kualitas visual dari bangunan bersejarah yang terletak di koridor jalan Kayutangan pada siang hari.

Lokasi penelitian adalah berada di Jalan Basuki Rahmat, Klojen, Malang. Hal ini dikenal sebagai “Kayutangan." Berbagai bangunan kolonial di kota ini terletak di "Kayutangan." Area ini dipilih sebagai lokasi penelitian ini karena sejarah dan ada beberapa perdebatan tentang lokasi ini di antara para ahli sejarah, tokoh masyarakat dan kedua organisasi publik dan swasta. Jumlah bangunan bersejarah di koridor jalan ini terdapat 29 gedung. Bangunan-bangunan ini digunakan sebagai toko dan gedung perkantoran saat ini.

Populasi adalah seluruh objek yang memiliki karakteristik khusus untuk diamati. Sampel adalah kelompok yang lebih kecil yang mewakili populasi. Ada dua jenis populasi penelitian ini, bangunan bersejarah, dan pengguna atau pengamat. 
Ada 31 bangunan bersejarah yang terletak di sepanjang koridor jalan Kayutangan. 29 dari bangunan tersebut adalah bangunan kolonial. Kriteria pengambilan sampel adalah bangunan kolonial yang dibangun setidaknya 50 tahun yang lalu, memiliki kontribusi khusus terhadap sejarah, pengetahuan, pendidikan, agama, dan budaya yang mengandung nilai budaya dan yang lebih penting, tetap utuh.

Berdasarkan kriteria, terdapat sepuluh gedung menjadi sampel. Bangunan-bangunan ini tetap utuh digunakan baik sebagai perumahan, gedung perkantoran atau bangunan komersial, lebih dari 100 $\mathrm{m} 2$ dan tidak tercakup oleh media apa pun yang mencegah pengamat dari mengevaluasi kualitas visual mereka. Sampel adalah sebagai berikut:
1. AVIA
6. Optik Surya
2. Gedung PLN
7. Rumah Namsin
3. Toko LIE
8. Toko Riang
4. Rajabally
9. Gereja Kayutangan
5. CIMB Niaga
10. Toko OEN

Responden yang berpartisipasi dalam penelitian ini adalah individu yang tinggal di Malang dan melakukan kegiatan mereka di sepanjang koridor jalan Kayutangan. Mereka mengevaluasi kualitas visual dari bangunan bersejarah yang terletak di koridor jalan pada siang. Teknik pengambilan sampel adalah purposive sampling (teknik pengambilan sampel nonprobability).

Penelitian ini terdiri dari tiga kelompok menggunakan teknik pengambilan sampel yang berbeda, yaitu pengguna jalan, praktisi dan akademisi. Pengguna jalan menggunakan teknik sampling kebetulan. Sedangkan akademisi dan praktisi menggunakan teknik purposive sampling. Total sampel adalah 100 orang, dan mereka mengevaluasi kualitas visual dari bangunan menggunakan Semantic Differential Scale (SD).

Dalam penelitian ini populasi tidak diketahui, sehingga untuk menentukan jumlah sampel yang diambil dengan rumus sebagai berikut.

$\mathrm{N}=0,25 \times\left(\frac{Z a / 2}{\varepsilon}\right)^{2}$

\section{Catatan:}

$N \quad=$ jumlah responden

a $\quad=$ margin of error $(10 \%)$

$\mathrm{Za} / 2$ = values obtained from normal tables for confidence levels (level of research confidence $95 \%=$ $1,96)$

$\mathrm{N}=0,25 \times\left(\frac{1,96}{0.1}\right)^{2}=96,04=100$ responden

Skor ini digunakan untuk membahas penilaian kualitas visual selama siang hari.

Ada 14 variabel dalam mengevaluasi kualitas visual dari bangunan bersejarah tersebut, yang berasal dari penelitian sebelumnya seperti Santosa et al. (2012, 2013), Askari et al. (2009), Widiantoro et al. (2015), Karisztia et al. (2008) dan Fauziah et al. (2012) membahas tentang Bentuk Massa dan Dasar Bangunan. Liu et al. (2015), Santosa et al. (2012, 2013), Manurung (2008), Askari et al. (2009), Kamurahan 
et al. (2014), Fauziah et al. (2012), Jennath dan Nidhish (2016) membahas tentang Warna (Characteristis, Saturation, Brightness). Fauziah et al. (2012), Jennath dan Nidhish (2016), Askari et al. (2009) dan Manurung (2008) membahas tentang Texture. Penelitian lain seperti Nurmasari (2008) dan Kamurahan et al. (2014) membahas tentang prinsip desain kekompakkan, keseimbangan, dan fungsi.

Tabel 1. Table variabel and pengukuran semantik

\begin{tabular}{llllllllll}
\hline Variable (Aspek Amatan) & & \multicolumn{7}{l}{ Measurement of the rating scale (negative-positive) } \\
\hline Building Mass & Closed & 1 & 2 & 3 & 4 & 5 & 6 & 7 & Open \\
Basic Form & Simple & 1 & 2 & 3 & 4 & 5 & 6 & 7 & Complicated \\
Color Characteristics & Cold & 1 & 2 & 3 & 4 & 5 & 6 & 7 & Warm \\
Saturation & Faded & 1 & 2 & 3 & 4 & 5 & 6 & 7 & Bright \\
Brightness & Dark & 1 & 2 & 3 & 4 & 5 & 6 & 7 & Light \\
Texture & Firm & 1 & 2 & 3 & 4 & 5 & 6 & 7 & Soft \\
Ambiance & Lonesome & 1 & 2 & 3 & 4 & 5 & 6 & 7 & Lively \\
Lighting Effect & Ugly & 1 & 2 & 3 & 4 & 5 & 6 & 7 & Beautiful \\
Harmony & Not suitable & 1 & 2 & 3 & 4 & 5 & 6 & 7 & Suitable \\
Attractiveness & Common & 1 & 2 & 3 & 4 & 5 & 6 & 7 & Interesting \\
Arts & Inartistic & 1 & 2 & 3 & 4 & 5 & 6 & 7 & artistic \\
Effect & Shabby & 1 & 2 & 3 & 4 & 5 & 6 & 7 & Excellent \\
Lighting security & Unsafe & 1 & 2 & 3 & 4 & 5 & 6 & 7 & Safety \\
Visual Comfort & Unpleasant & 1 & 2 & 3 & 4 & 5 & 6 & 7 & pleasant \\
\hline
\end{tabular}

(Sumber: Askari \& Dola, 2009; Jennath \& Nidhish, 2016; Liu et. al., 2015; Mahmoudi \& Ahmad, 2015; Perovic \& Folic, 2012; Anggraini, 2007; Gokhale, 2013; Hafiz, 2015; Rankel, 2014; Cafuta, 2014; Mahmoudi \& Ahmad, 2015; Widiantoro et.al., 2015; Fauziah et. al., 2012; Karisztia et.al., 2008; Santosa et. al., 2013- 2014.)

Untuk menganalisis persepsi publik, kualitas visual bangunan bersejarah di koridor Kayutangan menggunakan pengukuran Semantic Differential Scale (SD). Pengukuran ini terdiri dari tujuh skala menggunakan kata-kata yang berlawanan. Penilaian negatif berada di sisi kiri dan yang positif berada di sebelah kanan.

Untuk efisiensi dan membandingkan kualitas visual bangunan bersejarah selama siang hari, hasil kuesioner diformulasikan ke dalam tabel menggunakan formulir web Google, Microsoft Excel, dan program analsis data SPSS. Google Form digunakan untuk mendapatkan penilaian orang dari kuesioner yang telah disediakan. Setelah itu, data yang diperoleh diubah ke format Microsoft Excel. Data yang telah disusun akan dianalisis menggunakan program SPSS untuk mendapatkan penilaian rata-rata orang dan Multiple Linear Regression untuk mendapatkan aspek-aspek yang dipengaruhi oleh masyarakat.

\section{HASIL DAN PEMBAHASAN}

Penelitian ini mengevaluasi pengaruh pencahayaan pada kualitas visual bangunan bersejarah pada siang hari. Berdasarkan 14 variabel, responden dapat memberikan penilaian kualitas visual dari bangunan bersejarah tersebut.

Gedung AVIA adalah salah satu bangunan bersejarah di Malang yang lokasinya berada di koridor jalan Kayutangan. Bangunan lain yang terletak di koridor Kayutangan adalah gedung kantor Perusahaan Listrik Negara (PLN) bernama N.V. Algemeene Nederlandsch-Indische Electricities Maatschappij (ANIEM) yang dibangun pada tahun 1930. Bangunan ini berada di seberang AVIA Building. Penggunakan aplikasi 
SPSS digunakan untuk menganalisis skor rata-rata kualitas visual bangunan AVIA dan Perusahaan Listrik Negara (PLN) pada siang hari.

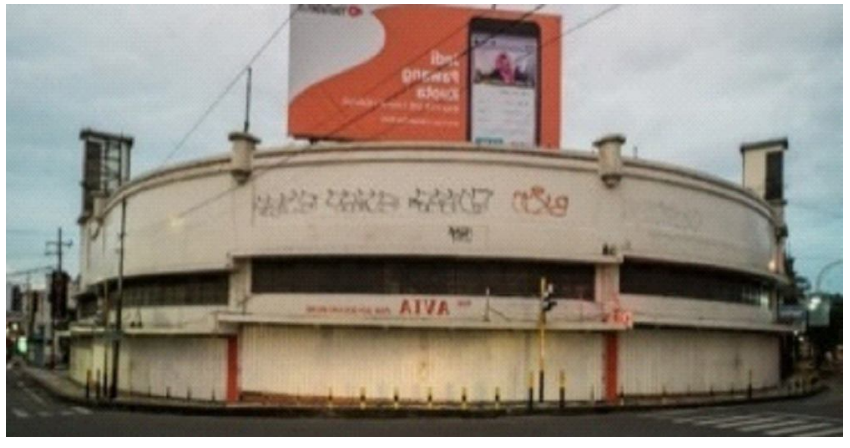

(a)

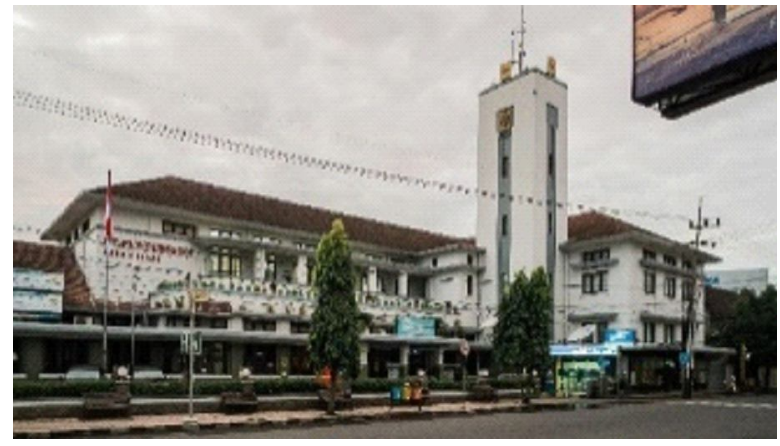

(b)

Gambar 1. a. Gedung Avia, b. Gedung PLN

Tabel 2. Rata Penilaian "AVIA" (AVIA Supermarket) and State Electric Company building

\begin{tabular}{clcc}
\hline \multicolumn{1}{c}{$\begin{array}{c}\text { Aspek Amatan } \\
\text { (negative-positive) }\end{array}$} & $\begin{array}{c}\text { Rata Penilaian } \\
\text { AVIA }\end{array}$ & $\begin{array}{c}\text { Rata Penilaian } \\
\text { PLN }\end{array}$ \\
\hline 1 & & & 5.35 \\
2 & Building Mass (Closed - open) & 4.43 & 4.78 \\
3 & Basic Form (Simple - complicated) & 5.45 & 4.76 \\
4 & Color Characteristics (Cold - warm) & 3.85 & 5.17 \\
5 & Baturation (Faded - bright) & 5.00 & 5.44 \\
6 & Texture (Firm - soft) & 4.69 & 4.86 \\
7 & Ambiance (Lonesome - lively) & 3.78 & 5.05 \\
8 & Lighting Effect (Ugly - beautiful) & 4.53 & 5.20 \\
9 & Harmony (Not suitable - suitable) & 4.48 & 5.44 \\
10 & Attractiveness (Common - interesting) & 4.99 & 5.59 \\
11 & Arts (Inartistic - artistic) & 4.96 & 5.47 \\
12 & Effect (Shabby - excellent) & 4.57 & 5.25 \\
13 & Lighting security (Unsafe - safety) & 4.96 & 5.57 \\
14 & Visual Comfort (Unpleasant - pleasant) & 4.96 & 5.52 \\
\hline & Grand Mean & 4.64 & 5.25 \\
\hline
\end{tabular}

Keterangan: skala pengukuran menggunakan skala 1 sampai 7 (negatif ke positif)

100 responden menyelesaikan kuisioner, dan hasilnya disusun dan ditabulasikan (lihat Tabel 2). Menurut tabel itu, nilai rata-rata setiap bangunan bersejarah Avia berkisar antara 4 hingga 5 dengan 4,64 poin di siang hari. Sedangkan di gedung Perusahaan Listrik Negara, yang berkisar 5-6 dengan 5,25 poin pada siang hari. Hasil ini menunjukkan bahwa penilaian siang hari di gedung bersejarah Avia dan Gedung PLN memiliki penilaian pencahayaan yang baik pada siang hari.

Toko LIE adalah bangunan bersejarah ketiga, dan toko tertua di koridor Kayutangan. Bangunan bersejarah keempat adalah Rajabally. Rajabally memiliki dua gedung dengan bentuk arsitektur yang sama. 


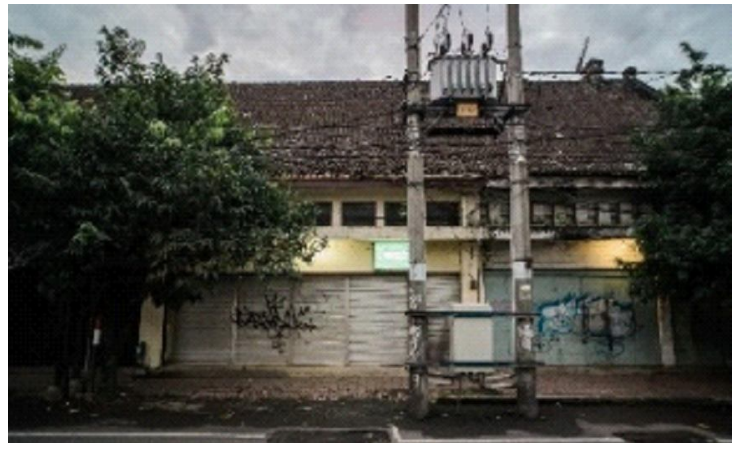

(a)

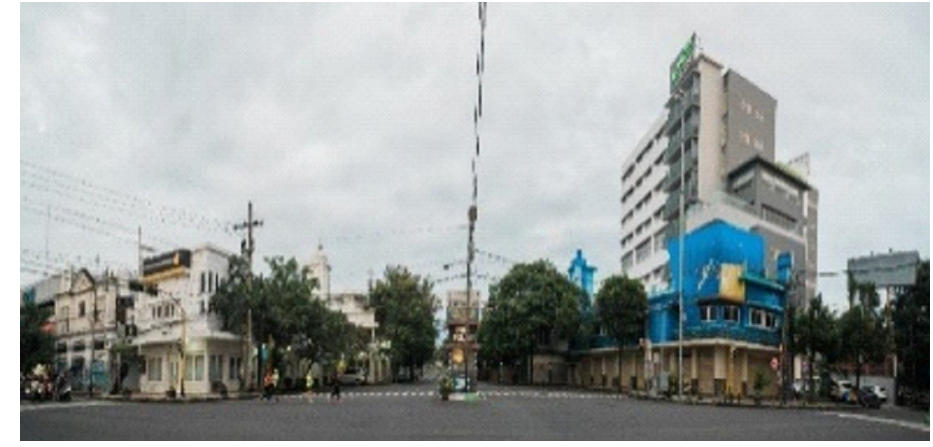

(b)

Gambar 2. a. Toko LIE, b. Gedung Kembar Rajabally

Tabel 3. Rata Penilaian LIE Store and Rajabally Building

\begin{tabular}{clcc}
\hline No & \multicolumn{1}{c}{$\begin{array}{c}\text { Aspek Amatan } \\
\text { (negative-positive) }\end{array}$} & $\begin{array}{c}\text { Rata Penilaian } \\
\text { LIE }\end{array}$ & $\begin{array}{c}\text { Rata Penilaian } \\
\text { Rajabally }\end{array}$ \\
\hline 1 & Building Mass (Closed - open) & 3.14 & 5,26 \\
2 & Basic Form (Simple - complicated) & 4.62 & 5,02 \\
3 & Color Characteristics (Cold - warm) & 3.80 & 4,79 \\
4 & Saturation (Faded - bright) & 3.43 & 5,02 \\
5 & Brightness (Dark - light) & 3.81 & 5,07 \\
6 & Texture (Firm - soft) & 3.78 & 4,95 \\
7 & Ambiance (Lonesome - lively) & 3.34 & 4,93 \\
8 & Lighting Effect (Ugly - beautiful) & 3.63 & 5,09 \\
9 & Harmony (Not suitable - suitable) & 3.86 & 5,03 \\
10 & Attractiveness (Common - interesting) & 4.31 & 5,23 \\
11 & Arts (Inartistic - artistic) & 3.83 & 5,07 \\
12 & Effect (Shabby - excellent) & 3.73 & 4,98 \\
13 & Lighting security (Unsafe - safety) & 4.20 & 5,16 \\
14 & Visual Comfort (Unpleasant - pleasant) & 4.36 & 5,18 \\
\hline & Grand Mean & 3.85 & 5.25 \\
& x<4= negative value, & & \\
\hline
\end{tabular}

Keterangan: skala pengukuran menggunakan skala 1 sampai 7 (negatif ke positif)

100 responden menyelesaikan kuisioner, dan hasilnya disusun dan ditabulasikan (lihat Tabel 3). Menurut tabel itu, nilai rata-rata setiap bangunan LIE Store berkisar antara 3 hingga 4 dengan 3,85 poin di siang hari. Sementara di gedung Perusahaan Listrik Negara (PLN), yang berkisar 5-6 dengan 5,05 poin pada siang hari. Hasil ini menunjukkan bahwa penilaian selama siang hari di gedung LIE Store memiliki penilaian negatif. Namun, pembangunan Rajabally memiliki penilaian positif selama siang hari.

CIMB Niaga adalah bangunan bersejarah kelima, dan toko tertua di koridor Kayutangan. Bangunan bersejarah keenam adalah Optic Surya. Bangunan ini menjual berbagai jenis kacamata sejak awal bangunan dibangun hingga sekarang. 


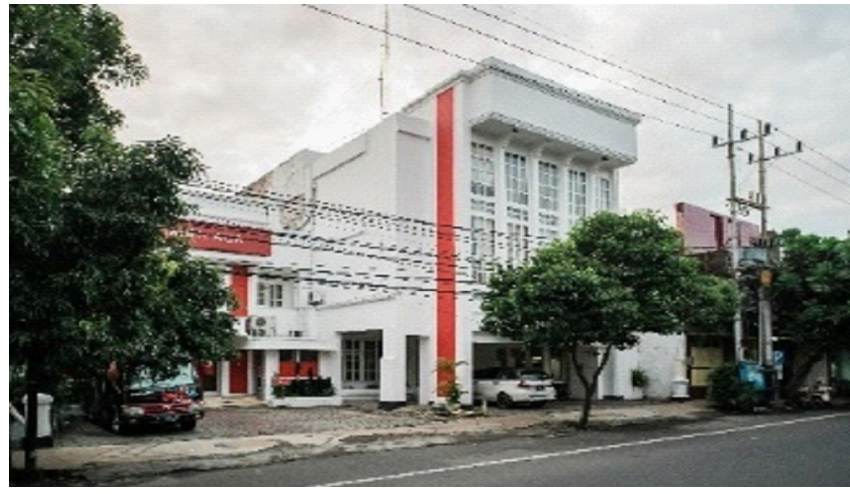

(a)

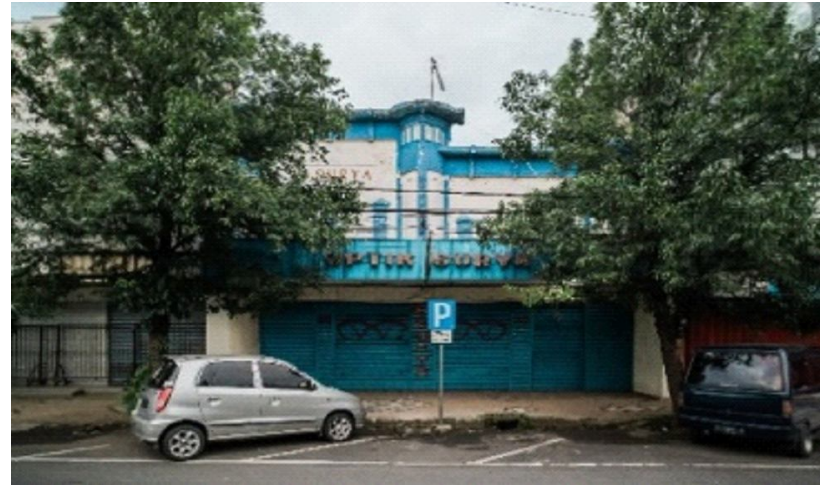

(b)

Gambar 3. a. CIMB Niaga, b. Optik Surya

Tabel 5. Rata Penilaian CIMB Niaga and Optik Surya

\begin{tabular}{clcc}
\hline No & \multicolumn{1}{c}{$\begin{array}{c}\text { Aspek Amatan } \\
\text { (negative-positive) }\end{array}$} & $\begin{array}{c}\text { Rata Penilaian } \\
\text { CIMB Niaga }\end{array}$ & $\begin{array}{c}\text { Rata Penilaian } \\
\text { Optic Surya }\end{array}$ \\
\cline { 3 - 4 } & \multicolumn{1}{c}{ Day } & Day \\
\hline 1 & Building Mass (Closed - open) & 5.66 & 4.27 \\
2 & Basic Form (Simple - complicated) & 5.27 & 5.07 \\
3 & Color Characteristics (Cold - warm) & 5.15 & 4.40 \\
4 & Saturation (Faded - bright) & 5.72 & 4.88 \\
5 & Brightness (Dark - light) & 5.69 & 4.47 \\
6 & Texture (Firm - soft) & 5.54 & 4.52 \\
7 & Ambiance (Lonesome - lively) & 5.46 & 4.35 \\
8 & Lighting Effect (Ugly - beautiful) & 5.68 & 4.47 \\
9 & Harmony (Not suitable - suitable) & 5.59 & 4.57 \\
10 & Attractiveness (Common - interesting) & 5.65 & 4.67 \\
11 & Arts (Inartistic - artistic) & 5.48 & 4.70 \\
12 & Effect (Shabby - excellent) & 5.61 & 4.51 \\
13 & Lighting security (Unsafe - safety) & 5.77 & 4.82 \\
14 & Visual Comfort (Unpleasant - pleasant) & 5.78 & 4.88 \\
\hline & Grand Mean & & 4.61 \\
& x<4 = negative value, & 5.58 & \\
\hline
\end{tabular}

Keterangan: skala pengukuran menggunakan skala 1 sampai 7 (negatif ke positif)

100 responden menyelesaikan kuisioner, dan hasilnya disusun dan ditabulasikan (lihat Tabel 4). Menurut tabel itu, nilai rata-rata setiap gedung CIMB Niaga berkisar antara 5 hingga 6 dengan 5,58 poin pada siang hari. Sedangkan di gedung Optic Surya, itu berkisar antara 4 hingga 5 dengan 4,61 poin di siang hari. Hasil ini menunjukkan bahwa penilaian selama siang hari di gedung CIMB Niaga dan Optik Surya memiliki penilaian positif selama siang.

Rumah Namsin adalah bangunan bersejarah ketujuh dan rumah tertua di koridor Kayutangan. Rumah Namsin yang didirikan tahun 1900 tanpa mengubah gaya bangunan hingga sekarang. Bangunan bersejarah kedelapan adalah Toko Riang. Bangunan ini menjual berbagai macam pakaian dan banyak asesoris sejak awal gedung ini dibangun hingga sekarang. 


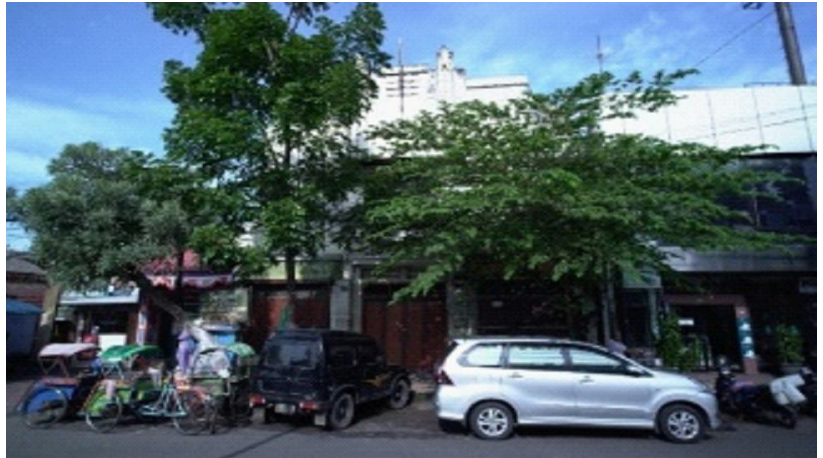

(a)

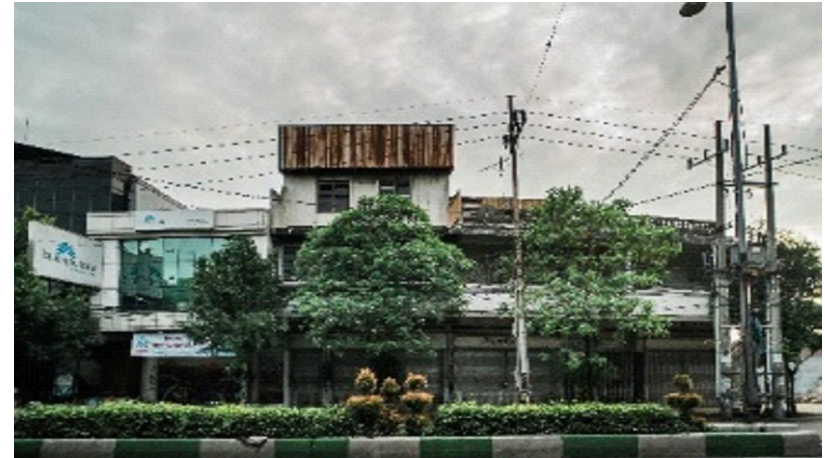

(b)

Gambar 4. a. Rumah Namisn, b. Toko Riang

Table 5. Rata Penilaian Rumah Namsin and Toko Riang

\begin{tabular}{clcc}
\hline No & \multicolumn{1}{c}{$\begin{array}{c}\text { Aspek Amatan } \\
\text { (negative-positive) }\end{array}$} & $\begin{array}{c}\text { Rata Penilaian } \\
\text { Rumah Namsin }\end{array}$ & $\begin{array}{c}\text { Rata Penilaian } \\
\text { Toko Riang }\end{array}$ \\
\hline 1 & Building Mass (Closed - open) & 3.62 & 3.94 \\
2 & Basic Form (Simple - complicated) & 4.59 & 4.88 \\
3 & Color Characteristics (Cold - warm) & 3.73 & 3.95 \\
4 & Saturation (Faded - bright) & 3.96 & 3.84 \\
5 & Brightness (Dark - light) & 4.02 & 4.16 \\
6 & Texture (Firm - soft) & 4.21 & 4.12 \\
7 & Ambiance (Lonesome - lively) & 3.79 & 3.95 \\
8 & Lighting Effect (Ugly - beautiful) & 4.06 & 4.04 \\
9 & Harmony (Not suitable - suitable) & 4.00 & 4.25 \\
10 & Attractiveness (Common - interesting) & 4.38 & 4.30 \\
11 & Arts (Inartistic - artistic) & 4.06 & 4.35 \\
12 & Effect (Shabby - excellent) & 4.43 & 4.01 \\
13 & Lighting security (Unsafe - safety) & 4.56 & 4.45 \\
14 & Visual Comfort (Unpleasant - pleasant) & & 4.68 \\
\hline & Grand Mean & 4.12 & 4.21 \\
\hline
\end{tabular}

Keterangan: skala pengukuran menggunakan skala 1 sampai 7 (negatif ke positif)

100 responden menyelesaikan kuisioner, dan hasilnya disusun dan ditabulasikan (lihat Tabel 5). Menurut tabel itu, nilai rata-rata Rumah Namsin berkisar antara 4 hingga 5 dengan 4,12 poin pada siang hari. Sementara di gedung Toko Riang, berkisar antara 4 hingga 5 dengan 4,21 poin di siang hari. Hasil ini menunjukkan bahwa penilaian selama siang hari di Gedung Namsin dan Gedung Riang Store memiliki penilaian positif.

Bangunan bersejarah kesembilan adalah Gereja Kayutangan, yang didirikan pada tahun 1905. Gereja ini adalah landmark Kota Malang, terutama dengan menara menjulang dengan bangunan bergaya Neogotik. Bangunan bersejarah terakhir adalah restoran OEN. "OEN Resaturant" adalah salah satu restoran tertua milik keluarga yang masih dijalankan pada tahun 1936 sampai sekarang di Kota Malang. 


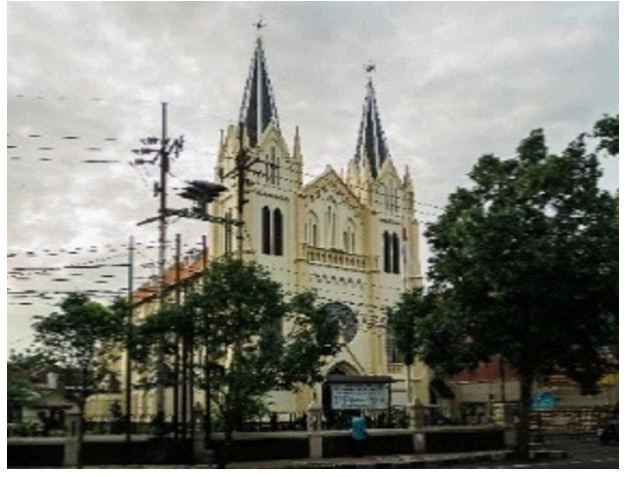

(a)

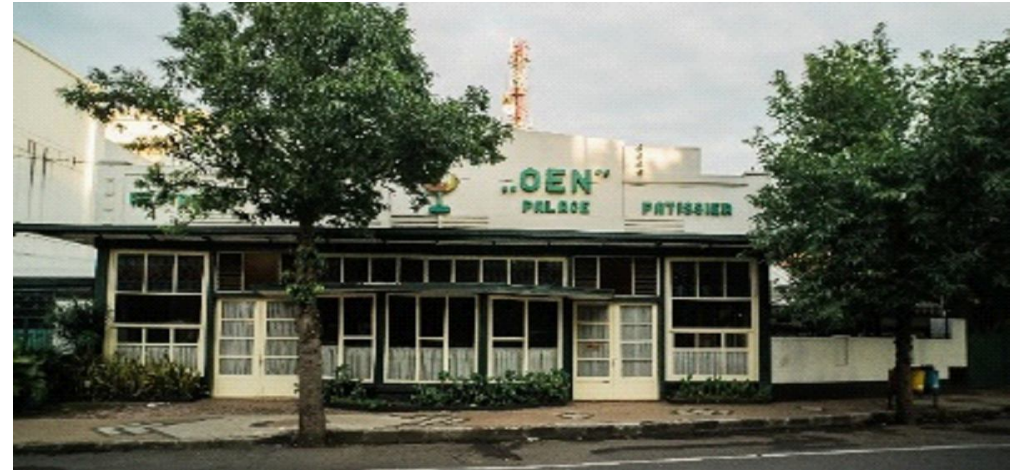

(b)

Gambar 5. a. Gereja Kayutangan, b. Toko OEN

Table 6. Average Score of Kayutangan Church and OEN Restaurant

\begin{tabular}{clcc}
\hline No & \multicolumn{1}{c}{$\begin{array}{c}\text { Aspek Amatan } \\
\text { (negative-positive) }\end{array}$} & $\begin{array}{c}\text { Rata Penilaian } \\
\text { Gereja Kayutangan }\end{array}$ & $\begin{array}{c}\text { Rata Penilaian } \\
\text { Toko OEN }\end{array}$ \\
\hline 1 & Building Mass (Closed - open) & 5.16 & 6.01 \\
2 & Basic Form (Simple - complicated) & 4.20 & 5.62 \\
3 & Color Characteristics (Cold - warm) & 5.30 & 5.42 \\
4 & Saturation (Faded - bright) & 5.48 & 5.61 \\
5 & Brightness (Dark - light) & 5.48 & 5.69 \\
6 & Texture (Firm - soft) & 5.02 & 5.44 \\
7 & Ambiance (Lonesome - lively) & 5.23 & 5.64 \\
8 & Lighting Effect (Ugly - beautiful) & 5.57 & 5.74 \\
9 & Harmony (Not suitable - suitable) & 5.53 & 5.73 \\
10 & Attractiveness (Common - interesting) & 5.75 & 5.92 \\
11 & Arts (Inartistic - artistic) & 5.79 & 5.69 \\
12 & Effect (Shabby - excellent) & 5.64 & 5.59 \\
13 & Lighting security (Unsafe - safety) & 5.60 & 5.78 \\
14 & Visual Comfort (Unpleasant - pleasant) & 5.67 & 5.82 \\
\hline & Grand Mean & & \\
& x 4 = negative value & 5.39 & 5.69 \\
\hline
\end{tabular}

Keterangan: skala pengukuran menggunakan skala 1 sampai 7 (negatif ke positif)

100 responden menyelesaikan kuisinoer, dan hasilnya disusun dan ditabulasikan (lihat Tabel 5). Menurut tabel itu, nilai rata-rata setiap Gereja Kayutangan berkisar 5-6 dengan 5,39 poin pada siang hari. Sementara di OEN Restaurant, yang berkisar 5-6 dengan 5,69 poin pada siang hari. Hasil ini menunjukkan bahwa penilaian selama siang hari di Gereja Kayutangan dan Toko OEN memiliki penilaian positif. 


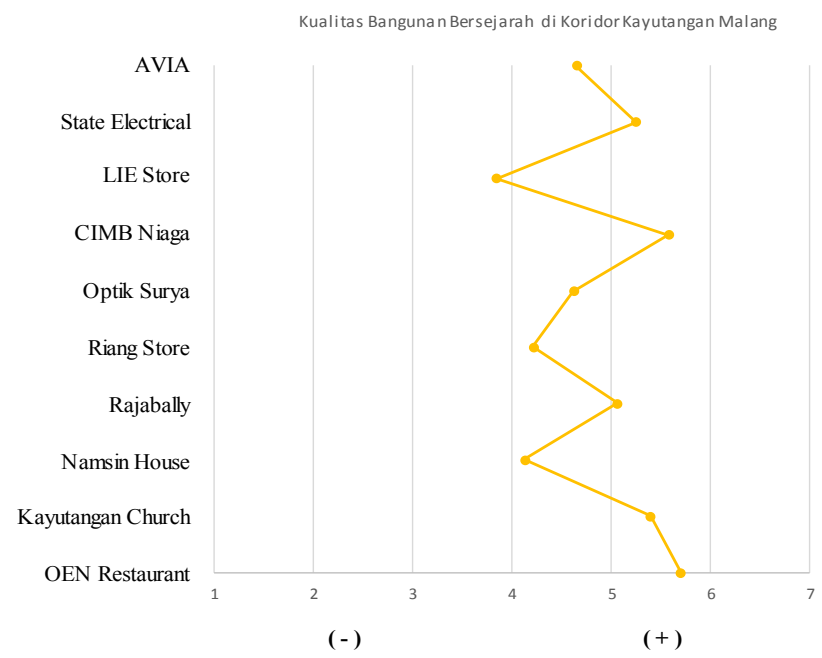

Gambar 6. Rata Penilaian ke sepuluh bangunan bersejarah Kayutangan

Berdasarkan Gambar 6, dapat disimpulkan bahwa Toko LIE adalah bangunan yang skor bangunan visual di siang hari lebih rendah dari nilai rata-rata. Ini membuktikan bahwa penilaian kualitas visual masyarakat pada siang hari dengan pencahayaan alami, sembilan dari kesepuluh bangunan bersejarah memiliki kualitas visual yang baik oleh masyarakat.

Berdasarkan 14 aspek yang telah dianalisis di setiap bangunan bersejarah, perlu diketahui variabelvariabel yang mempengaruhi kualitas visual bangunan bersejarah dengan melakukan analisis regresi linier berganda. Ke 14 variabel tersebut merupakan variabel bebas. Untuk mengetahui pengaruh tersebut perlu adanya variabel terikat yaitu penilaian terhadap kualitas visual fasad bangunan (Visual Quality Building). Hasil analisis regresi linier berganda yang akan ditampilkan adalah analisis pada siang hari.

Table 7. Statistik Deskriptif bangunan bersejarah di Kayutangan Malang.

\begin{tabular}{lccc}
\hline \multicolumn{1}{c}{ Aspect of Evaluation } & Descriptive Statistics & & Day \\
\cline { 2 - 4 } & & Mean & Std. Deviation \\
\hline Visual Quality Building & 4.91 & 1.695 & 1000 \\
Building Mass (Closed - open) & 4.68 & 1.895 & 1000 \\
Basic Form (Simple - complicated) & 4.95 & 1.629 & 1000 \\
Color Characteristics (Cold - warm) & 4.57 & 1.699 & 1000 \\
Saturation (Faded - bright) & 4.66 & 1.700 & 1000 \\
Brightness (Dark - light) & 4.88 & 1.614 & 1000 \\
Texture (Firm - soft) & 4.71 & 1.546 & 1000 \\
Ambiance (Lonesome - lively) & 4.55 & 1.733 & 1000 \\
Lighting Effect (Ugly - beautiful) & 4.80 & 1.592 & 1000 \\
Harmony (Not suitable - suitable) & 4.85 & 1.573 & 1000 \\
Attractiveness (Common - interesting) & 5.07 & 1.687 & 1000 \\
Arts (Inartistic - artistic) & 4.97 & 1.619 & 1000 \\
Effect (Shabby - excellent) & 4.80 & 1.522 & 1000 \\
Lighting security (Unsafe - safety) & 5.07 & 1.520 & 1000 \\
Visual Comfort (Unpleasant - pleasant) & 5.14 & 1.400 & 1000 \\
\hline
\end{tabular}

Predictors: (Constant), Visual Comfort, Structure, Color Characteristics, Attractiveness, Building Mass, Texture, Arts, Brightness, Ambiance, Harmony, Lighting security, Saturation, Effect, Lighting Effect

Dependent Variable: Visual Quality Building 
LOCAL WISDOM, Vol. 11 No. 1 Januari 2019

Local Wisdom Scientific Online Journal

Table 8. Model Summary bangunan bersejarah di Kayutangan Malang

\begin{tabular}{ccccc}
\hline & & \multicolumn{2}{c}{ Model Summary $^{\mathbf{b}}$} \\
\hline Model & R & R Square & Adjusted R Square & Std. Error of the Estimate \\
\hline 1 & $.876^{\mathrm{a}}$ & .767 & .763 & .825 \\
\hline
\end{tabular}

Predictors: (Constant), Visual Comfort, Structure, Color Characteristics, Attractiveness, Building Mass, Texture, Arts, Brightness, Ambiance, Harmony, Lighting security, Saturation, Effect, Lighting Effect

Dependent Variable: Visual Quality Building

Tabel 8 (MS) menunjukan nilai $R$ dan $\mathrm{R}^{2}$ pada siang hari. Nilai $\mathrm{R}$ menunjukkan korelasi sederhana dan 0,876 (kolom " $R$ "), yang menunjukkan korelasi tingkat tinggi pada siang hari. Nilai $R$ Square (kolom "R Square") menunjukkan berapa banyak variasi total dalam variabel dependen dapat dijelaskan oleh variabel independen. Dalam hal ini, 76,7\% data dapat dijelaskan, dengan nilai yang sangat besar.

Table 9. Test ANOVA pada bangunan bersejarah di Kayutangan malang

\begin{tabular}{lcrrr}
\hline & \multicolumn{5}{c}{ ANOVA $^{a}$} \\
\cline { 2 - 5 } & Sum of Squares & $d f$ & Mean Square & F \\
\hline Regression & 2201.241 & 14 & 157.232 & 231.180 \\
Residual & 669.923 & 985 & .680 & .000 \\
Total & 2871.164 & 999 & & \\
\hline
\end{tabular}

Predictors: (Constant), Visual Comfort, Structure, Color Characteristics, Attractiveness, Building Mass, Texture, Arts, Brightness, Ambiance, Harmony, Lighting security, Saturation, Effect, Lighting Effect

Dependent Variable: Visual Quality Building

Table 10. Regresi Liner Berganda pada Bangunan Bersejarah di Kayutangan Malang

\begin{tabular}{|c|c|c|c|c|c|}
\hline \multicolumn{6}{|c|}{ Coefficients ${ }^{a}$} \\
\hline \multicolumn{6}{|c|}{ Day } \\
\hline & \multicolumn{2}{|c|}{ Unstandardized Coefficients } & \multirow{2}{*}{$\begin{array}{c}\begin{array}{c}\text { Standardi-zed } \\
\text { Coefficients }\end{array} \\
\text { Beta }\end{array}$} & \multirow{2}{*}{$t$} & \multirow{2}{*}{ Sig. } \\
\hline & $B$ & Std. Error & & & \\
\hline (Constant) & -.394 & .117 & & -3.354 & .001 \\
\hline Building Mass (Closed - open) & .084 & .021 & .094 & 4.023 & .000 \\
\hline Basic Form (Simple - complicated) & .020 & .019 & .020 & 1.075 & .282 \\
\hline Color Characteristics (Cold - warm) & -.033 & .023 & -.033 & -1.429 & .153 \\
\hline Saturation (Faded - bright) & .053 & .030 & .053 & 1.794 & .073 \\
\hline Brightness (Dark - light) & .140 & .030 & .133 & 4.641 & .000 \\
\hline Texture (Firm - soft) & -.014 & .027 & -.012 & -.513 & .608 \\
\hline Ambiance (Lonesome - lively) & .016 & .028 & .017 & .585 & .559 \\
\hline Lighting Effect (Ugly - beautiful) & .011 & .037 & .010 & .299 & .765 \\
\hline Harmony (Not suitable - suitable) & .233 & .035 & .216 & 6.578 & .000 \\
\hline Attractiveness (Common - interesting) & .190 & .022 & .189 & 8.719 & .000 \\
\hline Arts (Inartistic - artistic) & .294 & .027 & .281 & 10.721 & .000 \\
\hline Effect (Shabby - excellent) & .079 & .037 & .071 & 2.153 & .032 \\
\hline Lighting security (Unsafe - safety) & .032 & .032 & .029 & 1.001 & .317 \\
\hline Visual Comfort (Unpleasant - pleasant) & -.026 & .037 & -.021 & -.710 & .478 \\
\hline
\end{tabular}

Predictors: (Constant), Visual Comfort, Structure, Color Characteristics, Attractiveness, Building Mass, Texture, Arts, Brightness, Ambiance, Harmony, Lighting security, Saturation, Effect, Lighting Effect

Dependent Variable: Visual Quality Building

Catatan: sig. $<.05$ = variable yang berpengaruh 


\section{Penilaian Persepsi Masyarakat terhadap Bangunan Besejarah di Koridor Kayutangan, Malang, Indonesia}

Tabel 10 menunjukkan bahwa variabel yang memiliki pengaruh yang signifikan terhadap Visual Quality Building pada siang hari adalah massa bangunan, kecerahan, harmoni, daya tarik, efek dan seni. Variabel yang paling berpengaruh pada kualitas visual bangunan bersejarah dari nilai tertinggi adalah Seni $(B=.294)$, Harmoni $(B=.233)$, Daya Tarik $(B=.190)$, Kecerahan $(B=.140)$, Massa Bangunan $(B=0,084)$, dan Efek $(B=0,079)$.

Variabel massa bangunan telah menjelaskan persepsi tentang berongga atau padat pada bangunan bersejarah. Dalam sebuah penelitian, Askari dan Dola (2009) telah membuktikan penilaian publik terhadap fasad bangunan bersejarah didasarkan pada bentuk, informasi tentang identitas dan latar belakang bangunan, atau pengetahuan, fungsi bangunan, dan keakraban. Ini membuktikan betapa pentingnya aspek massa bangunan. Hal yang sama juga disebutkan oleh Shirvani (1985), salah satu elemen karakter visual adalah massa bangunan.

Variabel kecerahan telah menjelaskan persepsi tentang warna gelap atau terang pada bangunan bersejarah. Fauziah et al. (2012) membuktikan bahwa salah satu pengaruh faktor visual kualitas fasad bangunan kolonial pasca modern adalah Warna Dimensi (tekstur, material, ornamen, warna, kecerahan). Utaberta et al. (2012) telah menyatakan pendapat berbeda. Mereka menyebutkan kecerahan memiliki korelasi kuat dengan fasad dan memiliki rata-rata terendah yang menegaskan bahwa kecerahan warna fasad memiliki penilaian negatif pada kualitas citra kota di fasad bangunan. Aspek estetika diperlukan untuk mengidentifikasi dan menentukan efek seni yang dibutuhkan yang dipengaruhi oleh bentuk bangunan serta oleh warna dan kualitas permukaan bangunan dan kecerahan lingkungan lingkungan dan sekitarnya (Górczewska \& Mroczkowska, 2015). Ini membuktikan bahwa kecerahan yang disebabkan oleh lingkungan mempengaruhi tampilan bangunan dan aspek lainnya. Sebagai salah satu variabel yang berpengaruh, kecerahan pada bangunan bersejarah sangat berpengaruh pada siang hari.

Variabel harmoni telah menjelaskan persepsi tentang cocok atau tidak cocok pada fasad bangunan bersejarah dengan pencahayaan siang. Korelasi antara geometri arsitektur dan desain dimulai dengan gagasan harmoni sebagai prinsip untuk semua ilmu dan ciptaan. Analisis pemahaman harmoni menunjukkan akar geometris dan gagasan unggul konsep ini untuk desain dan ilmu pengetahuan (Leopold, 2006). Estetika arsitektur adalah sistem kriteria koheren yang bersifat formal dan simbolis pada saat yang sama dan hal-hal formal berkaitan dengan pertanyaan proporsi, harmoni dan kontras, dan lain lain (Sotoudeh dan Abdullah, 2012). Dapat disimpulkan bahwa variable harmoni adalah salah satu aspek yang mempengaruhi estetika bangunan terhadap persepsi masyarakat.

Variabel daya tarik telah menjelaskan persepsi tentang umum atau menarik perhatian pada fasad bangunan bersejarah dengan pencahayaan siang. Adiwibowo et al. (2015) menyebutkan persepsi positif ditunjukkan oleh penilaian orang dan daya tarik eksterior bangunan bersejarah dapat dianggap sebagai poin utama dalam bangunan bersejarah. Daya tarik adalah salah satu aspek yang dibentuk oleh bentuk dominan di sekitar, abstraksi yang tidak mendominasi, dan pembentukan bangunan untuk menarik perhatian pengamat atau pengunjung ke wilayah historis (Wirawan, 2014). Ini membuktikan bahwa daya tarik bangunan bersejarah dipengaruhi oleh pencahayaan alami karena itu menunjukkan sisi detail bangunan bersejarah yang berbeda dari bangunan lain secara keseluruhan bangunan.

Variabel seni menjelaskan persepsi tentang inartistik atau artistik pada fasad bangunan. Seni Arsitektur dianggap sebagai pengetahuan seni, yaitu seni bangunan. Seni arsitektur bangunan dianggap sebagai 'rasa' yang didasarkan pada perasaan sebagai sumber ide (Sumalyo, 2005). Seni cahaya telah digunakan untuk bangunan bersejarah untuk mengekspresikan kepentingan budaya, sejarah, dan vi- 
sual (Zakaria dan Bahauddin, 2015). Seni bangunan bersejarah dapat ditampilkan dengan pencahayaan yang baik dan membuat detail seni dapat dilihat dengan mudah.

Variabel Effect (dampak) telah menjelaskan persepsi tentang lusuh atau sangat baik. Arti dari variabel Dampak adalah dampak pencahayaan pada lingkungan sekitar bangunan bersejarah. Manurung (2015) membuktikan bahwa persepsi visual pada siang hari menunjukkan bahwa informasi visual yang diperoleh dari bangunan bersejarah cukup lengkap sehingga elemen arsitektur dapat dinikmati dengan baik. Hasilnya pencahayaan di bangunan bersejarah seharusnya tidak membuat lingkungan sekitarnya menjadi lebih buruk seperti silau dan kesan negatif untuk bangunan dan pejalan kaki.

Kesimpulan dari penilaian kualitas visual bangunan bersejarah poada siang hari menunjukkan bahwa ada satu bangunan yang kualitas visualnya mendapat nilai rendah dibandingkan dengan bangunan-bangunan siang hari. Bangunan-bangunan tersebut adalah Toko LIE. Penilaian ini didukung oleh persepsi publik, dan telah dibuktikan dengan kualitas visual pada siang hari dipengaruhi oleh enam aspek (massa bangunan, kecerahan, daya tarik, harmoni, efek dan seni.

\section{KESIMPULAN}

Opini publik tentang kualitas visual dari bangunan bersejarah ini di siang menggambarkan pengaruh pencahayaan terhadap eksterior bangunan. Menurut responden, bangunan-bangunan ini memiliki skor kualitas visual yang lebih tinggi selama siang hari.

Satu dari kesepuluh bangunan (Toko LIE) memiliki kualitas visual yang rendah berdasarkan penilaian masyarakat pada siang hari. Bangunan tersebut adalah bangunan bersejarah paling favorit menurut publik di daerah tersebut. "Toko LIE" memiliki kualitas visual yang rendah pada siang hari. Ini membuktikan bahwa penilaian kualitas visual masyarakat pada siang hari dengan pencahayaan alami, sembilan dari kesepuluh bangunan bersejarah memiliki kualitas visual yang baik oleh masyarakat. Penilaian kualtias visual pada siang hari didukung oleh persepsi publik, dan telah dibuktikan dengan kualitas visual pada siang hari dipengaruhi oleh enam aspek. Aspek tersebut adalah massa bangunan, kecerahan, daya tarik, harmoni, efek dan seni. Variabel yang paling berpengaruh pada kualitas visual bangunan bersejarah dari urutan nilai tertinggi adalah aspek Seni, Harmoni, Daya Tarik, Kecerahan, Massa Bangunan, dan Efek pada hasil regresi berganda.

Peneliti masa depan diharapkan untuk melakukan studi yang membahas pencahayaan malam, misalnya seberapa besar pengaruh penempatan pencahayaan malam terhadap kualitas visual bangunan bersejarah atau jenis pencahayaan buatan yang menjadi nada paling cocok untuk bangunan bersejarah tersebut.

\section{REFeRENSI}

Adiwibowo, R. S., P. Widodo and I. Santosa (2015). “Correlations Between Public Appreciation of Historical Building and Intention to Visit Heritage Building Reused as Retail Store." Procedia - Social and Behavioral Sciences(184): 357-364.

Askari, A. H. and K. B. Dola (2009). “Influence of Building Façade Visual Elements on Its Historical Image: Case of Kuala Lumpur City, Malaysia." Journal of Design and Built Environment 5: pp. 49-59. 


\section{Penilaian Persepsi Masyarakat terhadap Bangunan Besejarah di Koridor Kayutangan, Malang, Indonesia}

Baskoro Azis, Herry Santosa, Jenny Ernawati

Fauziah, N., Antariksa and J. Ernawati (2012). "Kualitas Visual Fasade Bangunan Modern Pasca Kolonial di Jalan Kayutangan Malang.." Jurnal RUAS 10(2).

Jennath, K. A. and P. J. Nidhish (2016). "Aesthetic judgement and visual impact of architectural forms: a study of library buildings." Procedia Technology 24: pp. 1808-1818.

Kamurahan, S. R., Judi O. Waani dan Octavianus H.A.R. 2014. Studi Persepsi Masyarakat Terhadap Estetika Desain Fasade Bangunan Dengan Pendekatan Teori Subyektif: Studi Kasus di Koridor Boulevard on Business (BoB) Jalan Piere Tendean Manado. MEDIA MATRASAIN ISSN 18581137 Volume 11, No.2

Leopold, C. (2006). "GEOMETRY CONCEPTS IN ARCHITECTURAL DESIGN." 12TH INTERNATIONAL CONFERENCE ON GEOMETRY AND GRAPHICS T35: 1-9.

Liu, Y., J. Kang, Y. Zhang, D. Wang and L. Mao (2015). “Visual Comfort Is Affected By Urban Colorscape Tones In Hazy Weather." Frontiers of Architectural Research 5: pp. 453-465.

Lynch, K. (1969). Site Planning. Chicago, University of Chicago Press.

Mahmoudi, M. and F. Ahmad (2015). "Determinants of livable streets in Malaysia: A study of physical attributes of two streets in Kuala Lumpur." URBAN DESIGN International. 20: pp. 158-174.

Manurung, P. (2015). "Pendekatan Desain Pencahayaan Fasade Bangunan Bersejarah." Simposium Nasional RAPI XIV FT UMS.: pp. A8 - A12.

Perovic, S. and N. K. Folic (2012). "Visual Perception of Public Open Spaces in Niksic." Procedia - Social and Behavioral Sciences 68: pp. 921-933.

Sachari, A. (2007). Budaya Visual Indonesia: membaca makna perkembangan gaya visual karya desain di Indonesia abad ke-20. Jakarta, Erlangga.

Santosa, Herry., Shinji Ikagura, Takeshi Kobayasi. 2012. Study Of Visual Preferences On The Growth Of Urban Commercial Streetscape Through Building Owners Assesment. Diakses pada tanggal 2 Oktober 2017, www.researchgate.net/profile/Herry_Santosa/publication/264899753

Santosa, Herry., Shinji Ikagura, Takeshi Kobayasi. 2013. Visual Evaluation Of Urban Commercial Streetscape Through Building Owners Judgment. Diakses pada tanggal 2 Oktober 2017, https://www.researchgate.net/publication/264899527

Shirvani, H. (1985). Urban Design Process. New York, Van Nostrand Reinhold.

Sotoudeh, H. and W. M. Z. W. Abdullah (2012). "Affected Variables on Successful Infill Design in Urban Historic Context." Arts and Design Studies 3: 7-12.

Sumalyo, Y. (2005). Arsitektur Modern Akhir Abad XIX dan abad XX. Yogyakarta, Gajah Mada University Press.

Utaberta, N., A. Jalali, S. Johar, M. Surat and A. I. Che-Ani (2012). “Building Facade Study in Lahijan City, Iran: The Impact of Facade's Visual Elements on Historical Image." World Academy of Science, Engineering and Technology International Journal of Humanities and Social Sciences 6(7): 1839 - 1844.

Wirawan, I. M. Y. (2014). “PENERAPAN KONSEP ARSITEKTUR INFILL PADA BANGUNAN MUSEUM DALAM KAWASAN HERITAGE DI BANJARMASIN STUDI KASUS: MEMORIAL PARK SOEKARNO, BLITAR DAN MUSEUM NASIONAL, JAKARTA." E-Journal Graduate Unpar 1(2): 213-220.

Zakaria, S. A. and A. Bahauddin (2015). "Light Art for Historical Buildings: A Case Study of the Heritage Buildings in George Town, Penang Island." Procedia - Social and Behavioral Sciences(184): 345 - 350 